\title{
Changes in the Bacterioplankton Community Structure from Southern Gulf of Mexico During a Simulated Crude Oil Spill at Mesocosm Scale
}

\author{
Sonia S. Valencia-Agami ${ }^{1}$, Daniel Cerqueda-García ${ }^{2}$, Sébastien Putzeys ${ }^{2}$ (), \\ María Magdalena Uribe-Flores ${ }^{1}$, Norberto Ulises García-Cruz ${ }^{2}{ }^{\circledR}$, Daniel Pech ${ }^{3}$, \\ Jorge Herrera-Silveira ${ }^{1}$, M. Leopoldina Aguirre-Macedo ${ }^{1, *(1)}$ and José $Q$. García-Maldonado ${ }^{4, *}$ \\ 1 Centro de Investigación y de Estudios Avanzados del Instituto Politécnico Nacional, Mérida, Yucatán 97310, \\ Mexico; sonia.valencia@cinvestav.mx (S.S.V.-A.); maria.uribe@cinvestav.mx (M.M.U.-F.); \\ jorge.herrera@cinvestav.mx (J.H.-S.) \\ 2 Consorcio de Investigación del Golfo de México (CIGoM) - Centro de Investigación y de Estudios Avanzados \\ del Instituto Politécnico Nacional, Mérida, Yucatán 97310, Mexico; dacegabiol@ciencias.unam.mx (D.C.-G.); \\ sebastien.putzeys@cinvestav.mx (S.P.); norbertoulisesg@gmail.com (N.U.G.-C.) \\ 3 Laboratorio de Biodiversidad Marina y Cambio Climático, El Colegio de la Frontera Sur, Lerma Campeche, \\ Campeche 24500, Mexico; dpech@ecosur.mx \\ 4 CONACYT - Centro de Investigación y de Estudios Avanzados del Instituto Politécnico Nacional, Mérida, \\ Yucatán 97310, Mexico \\ * Correspondence: leopoldina.aguirre@cinvestav.mx (M.L.A.-M.); jose.garcia@cinvestav.mx (J.Q.G.-M.)
}

Received: 15 August 2019; Accepted: 10 October 2019; Published: 11 October 2019

\begin{abstract}
The southern Gulf of Mexico (sGoM) is highly susceptible to receiving environmental impacts due to the recent increase in oil-related activities. In this study, we assessed the changes in the bacterioplankton community structure caused by a simulated oil spill at mesocosms scale. The $16 \mathrm{~S}$ rRNA gene sequencing analysis indicated that the initial bacterial community was mainly represented by Gamma-proteobacteria, Alpha-proteobacteria, Flavobacteriia, and Cyanobacteria. The hydrocarbon degradation activity, measured as the number of culturable hydrocarbonoclastic bacteria $(\mathrm{CHB})$ and by the copy number of the alkB gene, was relatively low at the beginning of the experiment. However, after four days, the hydrocarbonoclastic activity reached its maximum values and was accompanied by increases in the relative abundance of the well-known hydrocarbonoclastic Alteromonas. At the end of the experiment, the diversity was restored to similar values as those observed in the initial time, although the community structure and composition were clearly different, where Marivita, Pseudohongiella, and Oleibacter were detected to have differential abundances on days eight-14. These changes were related with total nitrogen ( $p$ value $=0.030$ and $r^{2}=0.22$ ) and polycyclic aromatic hydrocarbons ( $p$ value $=0.048$ and $r^{2}=0.25$ ), according to PERMANOVA. The results of this study contribute to the understanding of the potential response of the bacterioplankton from sGoM to crude oil spills.
\end{abstract}

Keywords: light crude oil; bacterioplankton; southern Gulf of Mexico; 16S rRNA; mesocosm experiment

\section{Introduction}

The Gulf of Mexico (GoM) is a hotspot of biological diversity in which several oil-related industries are hosted, representing a high risk for oil spill disasters [1,2]. Two of the most important precedents of disaster were the Deepwater Horizon massive oil spill (DWH), which occurred in waters off Louisiana, USA during 2010 [3], in which more than 700,000 tons of crude oil was spilled into the GoM [4] and the 
Ixtoc-I oil spill during 1979, with more than 3.4 million barrels of crude oil spilled into the southern Gulf of Mexico (sGoM) for nine months [5].

Microbial communities have different responses to environmental perturbations [6,7] depending on the local environmental conditions (e.g., temperature, nutrients, oxygen, and salinity) and the duration of the disturbance [7]. In particular, for the northern GoM, several studies were conducted to detect changes in the bacterioplankton community caused by the DWH disturbance. It was observed that the microbial community responded to hydrocarbons only a few weeks after the oil spill, and it was related with the long-term adaptation to natural oil released into the environment [8-12]. Moreover, a dominance of microorganisms related with the consumption of aliphatic hydrocarbons was found at the initial stage of the spill (e.g., Oceanospirillales and Pseudomonas), while potential degraders of aromatic compounds (e.g., Colwellia and Cycloclasticus) were observed in a second stage $[8,11,13]$. Towards the end of the DWH spill, another shift in the microbial community was detected, where microorganisms involved in the degradation of complex organic matter as methylotrophs (e.g., Flavobacteriia, Alteromonadaceae, and Rhodobacteraceae) were dominant [14].

For over a decade, several simulations at mesocosm scale have been performed for the evaluation of the effect of hydrocarbons on planktonic microorganisms [15,16]. At this scale, it has been evidenced that low molecular weight polycyclic aromatic hydrocarbons (PAHs) can be degraded in a period of two days by several microorganisms [17]. The genus Cycloclasticus has been reported as one of the most important degraders of low molecular weight PAHs in the cold waters of Galicia, Spain [18]. Moreover, previous investigations at mesocosms scale have reported Alcanivorax as relevant microorganisms for cleaning oil-polluted marine systems, due to their high capability to use aliphatic compounds as carbon source [19-21]. For northern GoM, a rapid formation of microbe-oil aggregates and significant changes in the community composition from coastal surface water, after exposure to oil and Corexit dispersant, have been previously detected by mesocosms experiments. This rapid response of the microbial community was related to the presence of natural oil seepages in the GoM, and hence, the resident microbial communities are well-adapted to the presence of hydrocarbon in the environment [22].

The southern Gulf of Mexico is considered the largest base of the petroleum industry in Mexico, and explorations have been performed since 1970 and continue to increase until current times $[5,23]$. Despite several studies having been conducted after the Ixtoc-I disaster, the environmental alterations caused by this blowout remain scarcely assessed. Thus, contributing with the understanding of the potential response of the bacterioplankton from sGoM to crude oil spills, this study aimed to assess the effect of light crude oil over the native microbial community from sGoM, through a simulated oil spill under a mesocosm experiment.

\section{Materials and Methods}

\subsection{Sampling and Set-Up of the Mesocosm System}

Superficial seawater ( $<3 \mathrm{~m}$ depth) was collected during October 2017 at Progreso harbor, in the Yucatan Peninsula, Mexico (21 $20^{\prime \prime} \mathrm{N} ; 89^{\circ} 40^{\prime \prime} \mathrm{W}$ ). A single tank (2800 L total capacity; $1.75 \mathrm{~m}$ high; $1.55 \mathrm{~m}$ diameter) was filled up to $2500 \mathrm{~L}$ with seawater and transported to the CINVESTAV-IPN facilities in Merida, Yucatan. The mesocosm was equipped with an electric thruster to homogenize seawater temperature, oxygen, and salinity (Scheme 1). Before filling the tank, natural seawater was filtered through a nylon mesh $(200 \mu \mathrm{m})$ to remove mesoplankton and detritus. An acclimatization period of $24 \mathrm{~h}$ was considered in this study to allow the stabilization of the microbial communities to the experimental conditions. The experiment was performed outdoors with natural sunlight cycles during 15 days, with constant stirring at low speed $\left(0.125 \mathrm{~m} \mathrm{~s}^{-1}\right)$, and no nutrient addition was performed. For the determination of the microbial community composition in the seawater acclimatized to the mesocosm before crude oil addition, a sample was collected and catalogued as "Reference" (R). At day zero, the tank was supplemented with light crude oil (Ixtoc-I well; 31-39 API) at $80 \mathrm{mg}^{-1} \mathrm{~L}$. 


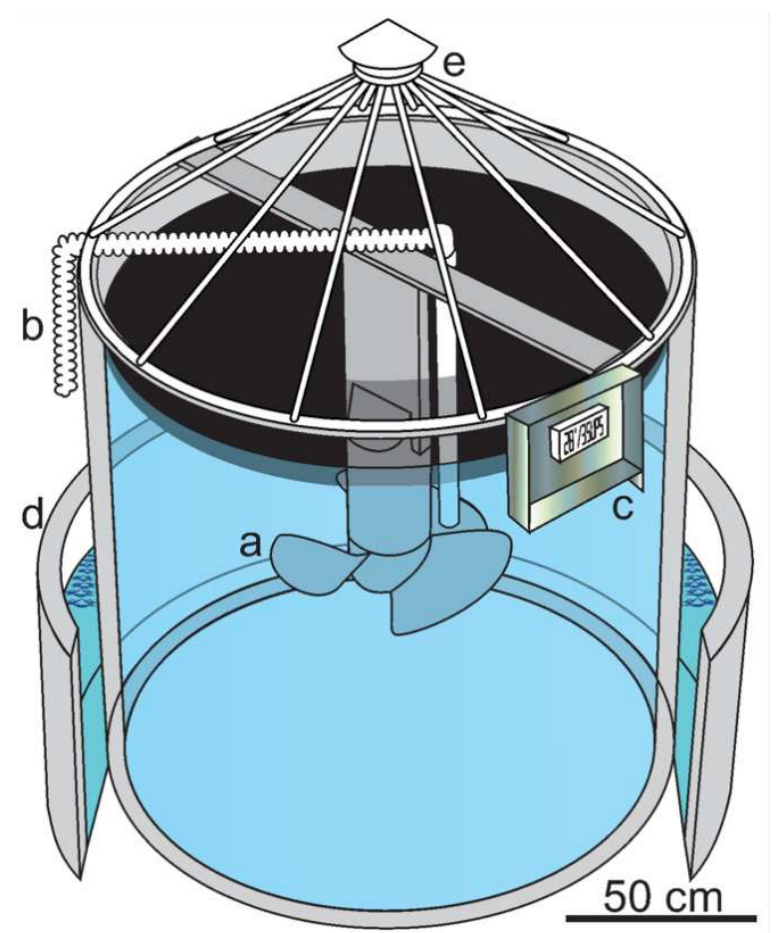

Scheme 1. Mesocosm design; (a) electric thruster, (b) plastic siphon for sampling, (c) remote control of salinity and temperature sensors, (d) water bath as cooler system, and (e) plastic coating.

During the experiment, one-meter depth water samples were collected from the mesocosm on days zero, two, four, six, eight, 10, and 14 to measure oxygen, salinity, temperature, nutrients, and hydrocarbons. The Winkler method was approached according to the steps suggested by Carrit and Carpenter [24] and Bryan et al. [25] for oxygen measurements. The entire content of each Winkler bottle was titrated manually during $\sim 3 \mathrm{~min}$ by colorimetric end-point detection [26]. A YSI probe was used to obtain measurements of salinity and temperature from seawater samples. For the inorganic nutrients, seawater samples were collected using sterile $1 \mathrm{~L}$ bottles and stored at $-20^{\circ} \mathrm{C}$ until analysis. Nitrate plus nitrite $\left(\mathrm{NO}_{3}{ }^{-}+\mathrm{NO}_{2}{ }^{-}\right)$, nitrite $\left(\mathrm{NO}^{2-}\right)$, orthophosphate $\left(\mathrm{PO}_{4}{ }^{3-}\right)$, and silicic acid $\left(\mathrm{SiO}_{4}{ }^{4-}\right)$ analyses were performed according to Strickland and Parsons [27], using an Agilent (Cary 60 UV-VIS) spectrophotometer. The detection limits for each inorganic nutrient were as follows: $0.03 \mu \mathrm{M}$ for nitrates, $0.01 \mu \mathrm{M}$ for nitrites, $0.02 \mu \mathrm{M}$ for phosphates, and $0.05 \mu \mathrm{M}$ for silicates. Total Nitrogen and carbon were quantified with $50 \mu \mathrm{L}$ seawater samples using a Thermo Scientific FLASH 2000 $\mathrm{CHNS/O}$ analyzer.

\subsection{Quantification of Hydrocarbons in the Water Column}

Crude oil concentration was measured as the total petroleum hydrocarbon (TPH). It was determined as the sum of aliphatic, aromatics (PAHs) and unresolved complex mixture (UCM) concentrations. Hydrocarbons were obtained by liquid-liquid extraction with $150 \mathrm{~mL}$ of dichloromethane and $4 \mathrm{~L}$ of one-meter depth seawater from the mesocosm. PAHs and UCM fractions were analyzed by high-resolution Gas Chromatography-Mass Spectroscopy (GC-MS) Perkin Elmer Clarus 500 and Gas Chromatography with Agilent 7890A (Santa Clara, CA, USA) equipped with a flame ionization detector (GC-FID) for aliphatic fraction.

\subsection{Estimation of Culturable Hydrocarbonoclastic Bacteria and Quantification of the alkB Gene}

Water samples ( $15 \mathrm{~mL}$ centrifugate tubes) were collected specifically for assessing the culturable hydrocarbonoclastic bacteria (CHB). Estimates of the number of $\mathrm{CHB}$ were obtained using the most probable number (MPN) method reported by $[23,28]$. The determination was performed using sterile 
tubes (10 mL), each containing $5 \mathrm{~mL}$ of sterile Bushnell-Hass (B-H) medium (Difco, Livonia, Michigan, USA) conditioned with $2 \% \mathrm{NaCl}, \mathrm{pH} 7$. Test tubes were inoculated with seawater from the mesocosm, light crude oil $\left(0.178 \mathrm{mg} \mathrm{L}^{-1}\right)$ as the sole carbon source, and resazurin as an indicator of bacterial growth. The quantification of the alkB gene, related to first-step hydroxylases involved in the metabolism of alkanes, was performed on a Rotor-Gene Q System (Qiagen, Hilden, Germany) with the primers and the protocol previously reported by Uribe-Flores et al. [29], with coefficient of determination $\left(r^{2}\right)$ of 0.98 and PCR amplification efficiency of $98.3 \%$.

\subsection{Bacterial Community Analyses}

Changes in the microbial community were followed by 16S rRNA Illumina sequencing. DNA extraction was performed using the PowerWater Sterivex DNA Isolation kit (Mo Bio Laboratories, Inc.), according to manufacturer's instructions. Seawater from the mesocosm was filtered ( $5 \mathrm{~L}$ ) through a $0.22 \mu \mathrm{m}$ Sterivex cartridge filter (Millipore Corp., Bedford, MA, USA) using a peristaltic pump. The quality of DNA extraction was evaluated by agarose gel (1\%) electrophoresis. Amplification of hypervariable V3 and V4 region of 16S rRNA was performed using the primers and the conditions suggested by Klindworth et al. [30]. Amplicons were purified with AMPure XP beads and indexed using the Nextera XT kit, according to the library preparation protocol recommended by the manufacturer. Indexed PCR products were purified and quantified with a Qubit ${ }^{\circledR} 3.0$ Fluorometer using the Qubit dsDNA HS Assay Kit (Life Technologies, Carlsbad, CA, USA). Amplicon size was verified by capillary electrophoresis at QIAxcel Advanced (QIAGEN, Valencia, CA, USA). Individual amplicons were diluted in $10 \mathrm{mM}$ Tris ( $\mathrm{pH}$ 8.5) and pulled at equimolar concentrations $(4 \mathrm{nM})$. Sequencing was carried out in CINVESTAV-Mérida using an Illumina-Miseq platform (Illumina, San Diego, CA, USA), with the MiSeq reagent kit V3 $(2 \times 300)$, following the manufacturer's recommendations.

\subsection{Bioinformatics and Statistics}

The demultiplexed paired-end reads $(2 \times 300)$, in the fastq format were processed with the QIIME2 pipeline (2018.8) [31]. The error correction and denoising to resolve the amplicon sequence variants (ASVs) were performed with the DADA2 plugin [32,33]. The length of sequences was 250 bp after trimming. Removing chimeras with the "consensus" method. The representative ASVs were taxonomically assigned with the V-SEARCH consensus taxonomy classifier plugin [34] using the SILVA database (v.128) as a reference. A phylogenetic tree was built with the reference ASVs with the FastTree algorithm [35]. The samples were rarefied at a sample depth of 30,000 reads, then transformed to percentage to obtain relative abundances. The abundance table was exported to the R environment, and the statistical analysis and visualization was performed with the phyloseq [36], vegan [37], and ggplot2 [38] libraries. Pairwise dissimilarities were calculated using UniFrac (weighted) metrics [39]. Each resulting dissimilarity matrix was used to visualize differences in the samples through principal coordinates ordination analysis (PCoA), using the "phyloseq" packages in R [40]. The data matrix was constructed with the means of each variable per day and was used as independent variables. To test significant differences between the discriminated groups according to sampled day and physiochemical parameters, similarities were analyzed by global and pairwise PERMANOVA tests, using "adonis" function in "vegan" [39]. $p$ values were obtained using 999 permutations. Shannon-Weaver diversity index was estimated in vegan library. A Kruskal Wallis test was performed to detect ASVs with differential abundance among three groups of samples based on changes in the Shannon index: Group 1 (samples R and zero), Group 2 (samples two, four, and six), and Group 3 (samples eight, 10, and 14). The taxonomic assignation of the differential ASVs, was improved, with the selection of the three best blast hits from the RefSeq NCBI database. Raw sequence data produced in this study was deposited in NCBI under the Bioproject accession number PRJNA560042 


\section{Results}

\subsection{Physicochemical Analyses}

All the physicochemical parameters measured through the 15 days of the mesocosms experiment are shown in Table 1 . The temperature ranged from $26.30-28.30{ }^{\circ} \mathrm{C}$, while the initial value for oxygen was $1.90 \mathrm{mg} \mathrm{L}^{-1}$, and the final concentration was $4.54 \mathrm{mg} \mathrm{L}^{-1}$ at day 14 . Salinity ranged from 35.53-36.70 PSU. Inorganic nutrients $\left(\mathrm{PO}_{4}, \mathrm{NO}_{2}, \mathrm{NO}_{3}, \mathrm{SiO}_{4}\right.$, and $\left.\mathrm{NH}_{4}\right)$, Total $\mathrm{C}$, and Total $\mathrm{N}$, had an increase from day zero to day 14 , however, this increment was more conspicuous in the nitrogen concentration range (0.04 to $1.55 \%)$.

Table 1. Physicochemical parameters during a simulated oil spill at mesocosm scale.

\begin{tabular}{|c|c|c|c|c|c|c|c|c|}
\hline Parameters & Reference & $\mathbf{0}$ & 2 & 4 & 6 & 8 & 10 & 14 \\
\hline \multirow{2}{*}{ Total_C (\%) } & 0.00 & 0.01 & 0.00 & 0.00 & 0.02 & 0.01 & 0.01 & 0.04 \\
\hline & \pm 0.008 & \pm 0.01 & \pm 0.02 & \pm 0.02 & \pm 0.01 & \pm 0.003 & \pm 0.04 & \pm 0.02 \\
\hline \multirow{2}{*}{ Total_N (\%) } & 0.39 & 0.33 & 0.39 & 0.48 & 0.41 & 0.51 & 0.64 & 1.55 \\
\hline & \pm 0.13 & \pm 0.03 & \pm 0.01 & \pm 0.01 & \pm 0.06 & \pm 0.07 & \pm 0.11 & \pm 0.08 \\
\hline Temperature $\left({ }^{\circ} \mathrm{C}\right)$ & 28.3 & 27.00 & 26.2 & 27.10 & 26.30 & 26.60 & 27.40 & 27.80 \\
\hline \multirow{2}{*}{$\mathrm{O}_{2}\left(\mathrm{mg} \mathrm{L}^{-1}\right)$} & 1.90 & 3.84 & 2.88 & 3.94 & 3.51 & 3.85 & 4.19 & 4.54 \\
\hline & \pm 0.06 & \pm 0.22 & \pm 0.17 & \pm 0.77 & \pm 0.26 & \pm 0.67 & \pm 0.22 & \pm 0.14 \\
\hline Salinity & 36.20 & 36.13 & 35.7 & 35.93 & 35.90 & 35.53 & 36.07 & 36.40 \\
\hline \multirow{2}{*}{$\mathrm{PO}_{4}\left(\mu \mathrm{mol} \mathrm{L}{ }^{-1}\right)$} & 0.89 & 0.61 & 0.75 & 1.18 & 0.91 & 1.20 & 1.09 & 1.04 \\
\hline & \pm 0.07 & \pm 0.02 & \pm 0.02 & \pm 0.09 & \pm 0.07 & \pm 0.05 & \pm 0.01 & \pm 0.14 \\
\hline \multirow{2}{*}{$\mathrm{NO}_{2}\left(\mu \mathrm{mol} \mathrm{L}{ }^{-1}\right)$} & 0.08 & 0.12 & 0.10 & 0.09 & 0.10 & 0.11 & 0.07 & 0.13 \\
\hline & \pm 0.01 & \pm 0.002 & \pm 0.009 & \pm 0.09 & \pm 0.006 & \pm 0.01 & \pm 0.02 & \pm 0.001 \\
\hline \multirow{2}{*}{$\mathrm{NO}_{3}(\mu \mathrm{mol} \mathrm{L}-1)$} & 4.34 & 0.77 & 0.43 & 0.38 & 0.41 & 0.23 & 0.17 & 0.49 \\
\hline & \pm 0.14 & \pm 0.03 & \pm 0.10 & \pm 0.06 & \pm 0.17 & \pm 0.17 & \pm 0.03 & \pm 0.04 \\
\hline \multirow{2}{*}{$\mathrm{SiO}_{4}(\mu \mathrm{mol} \mathrm{L}-1)$} & 3.26 & 0.09 & 0.38 & 0.16 & 0.25 & 0.12 & 0.60 & 0.25 \\
\hline & \pm 0.23 & \pm 0.02 & \pm 0.11 & \pm 0.16 & \pm 0.59 & \pm 0.01 & \pm 0.28 & \pm 0.11 \\
\hline \multirow{2}{*}{$\mathrm{NH}_{4}(\mu \mathrm{mol} \mathrm{L}-1)$} & 1.04 & 1.33 & 1.42 & 0.99 & 0.83 & 0.69 & 0.76 & 1.16 \\
\hline & \pm 0.04 & \pm 0.01 & \pm 0.01 & \pm 0.01 & \pm 0.02 & \pm 0.005 & \pm 0.06 & \pm 0.51 \\
\hline
\end{tabular}

\subsection{Estimation of the Bacterial Hydrocarbon Degrading Activity}

The initial values (day zero) of TPH concentration, CHB count, and alkB gene copies were $31.96 \mu \mathrm{g}$ $\mathrm{L}^{-1}, 70 \mathrm{CFU}$, and $2 \times 10^{5}$ copies $\mu \mathrm{L}^{-1}$, correspondingly. At day four, increases in these measurements were observed $\left(\mathrm{TPH}=6,503.87 \mu \mathrm{g} \mathrm{L}^{-1}, \mathrm{CHB}=23,000\right.$, and alkB gene $=1.2 \times 10^{6}$ copies $\left.\mu \mathrm{L}^{-1}\right)$. However, at day six the TPH concentration $\left(117.48 \mu \mathrm{g} \mathrm{L}^{-1}\right)$ and alkB gene copies $\left(5 \times 10^{4}\right.$ copies $\left.\mu \mathrm{L}^{-1}\right)$ decreased considerably. At the end of the experiment the values of TPH concentration and the alkB gene copies remained low $\left(595.03 \mu \mathrm{g} \mathrm{L}{ }^{-1}\right.$ and $7 \times 10^{3}$ copies $\mu \mathrm{L}^{-1}$, correspondingly); additionally, the CHB count decreased to $90 \mathrm{CFU}$ (Figure 1).

\subsection{Bacterial Community Structure and Composition}

Initial bacterioplankton community displayed the highest values of Shannon-Weaver index (Table 2). PCoA indicated that community structure after the oil addition was highly distant from the initial time (Figure 2). In terms of bacterial composition, the most abundant groups at the beginning of the experiment (day zero) were Gamma-proteobacteria, Alpha-proteobacteria, Verrucomicrobiae, Flavobacteriia, Cyanobacteria, and Sphingobacteriia (Figure 3a). During days two to four, Shannon-Weaver diversity $\left(\mathrm{H}^{\prime}\right)$ ranged from 4.66 to 4.74 (Table 2), and Alpha- and Gamma-proteobacteria reached their maximum relative abundances, respectively (Figure 3a). At a lower taxonomical level, Alteromonas increased considerably at day four. By the last period of the experiment (days eight to 14), the values of the diversity index were similar to those found at the initial time (Table 2). However, the final community composition was different, with notorious increases in the relative abundance of Sphingobacteriia and Bacteroidetes Incertae Sedis at the last day of the experiment. 
At the genus level, Marivita and Phaeodactillibacter showed an increment in their relative abundances from day eight to 14 (Figure $3 a, b)$. Genera with low relative abundance ( $<3 \%$ and classified as others) represented $40-60 \%$ of the total bacterioplankton composition throughout the experiment (Figure $3 \mathrm{~b}$ ). According to PERMANOVA, changes detected in the bacterial community were associated with the concentration of the aromatic fraction (Table S2) and total nitrogen concentration dissolved in the water column (Table 3).

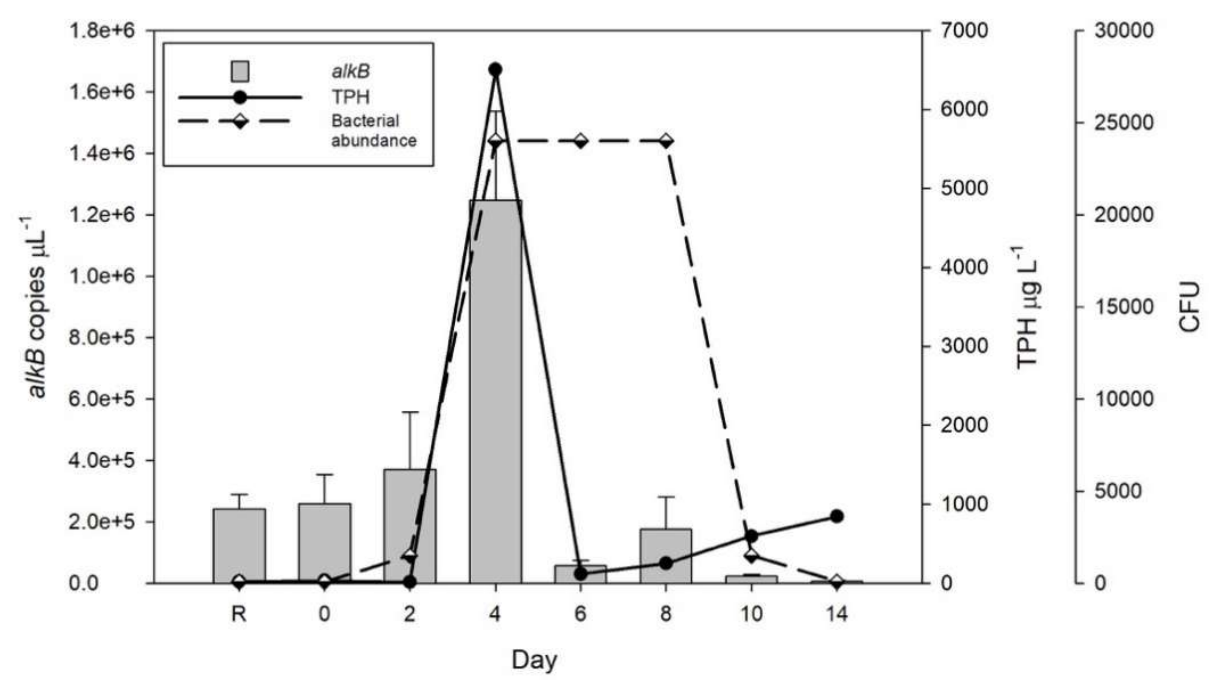

Figure 1. Abundances of culturable hydrocarbonoclastic bacteria, concentration of total petroleum hydrocarbons (TPH), and copy number of alkB gene during an oil spill simulation at mesocosm scale.

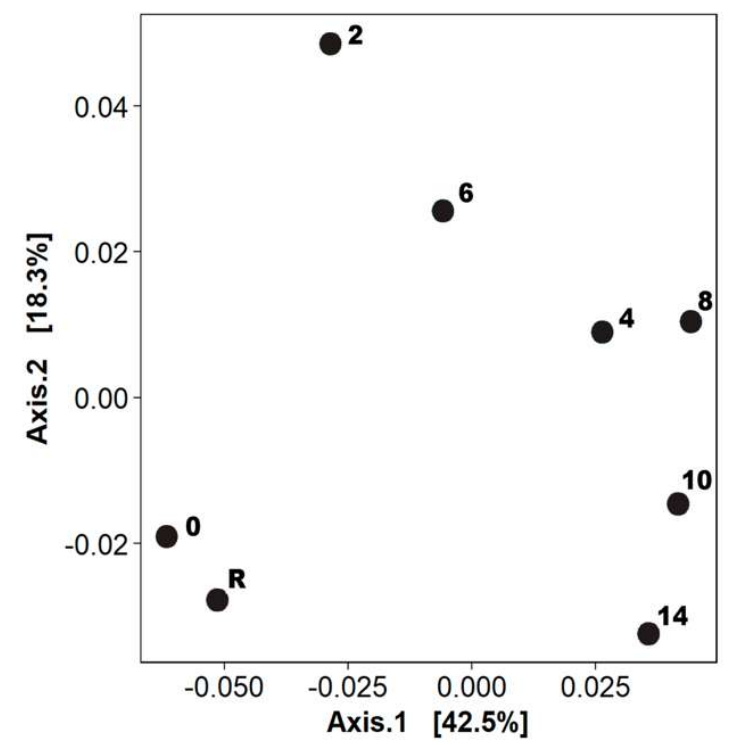

Figure 2. PCoA (weighted UniFrac) of bacterioplankton community during the mesocosm experiment according to amplicon sequence variants (ASVs) composition. Numbers indicate the sampling day. $\mathrm{R}=$ reference sample acclimatized to the mesocosm before crude oil addition. 
Table 2. Alpha diversity analyses from a simulated oil spill in mesocosms experiment.

\begin{tabular}{ccccc}
\hline Day & Input Reads & Clean Reads & Observed ASVs & Shannon \\
\hline $\mathrm{R}$ & 150,285 & 45,912 & 263 & 5.18 \\
0 & 133,342 & 39,671 & 236 & 5.02 \\
2 & 115,598 & 32,610 & 178 & 4.66 \\
4 & 113,562 & 34,066 & 196 & 4.74 \\
6 & 126,258 & 37,726 & 231 & 4.94 \\
8 & 135,164 & 39,719 & 234 & 5.08 \\
10 & 145,363 & 42,706 & 255 & 5.06 \\
14 & 293,188 & 64,015 & 317 & 5.08 \\
\hline
\end{tabular}

(a)

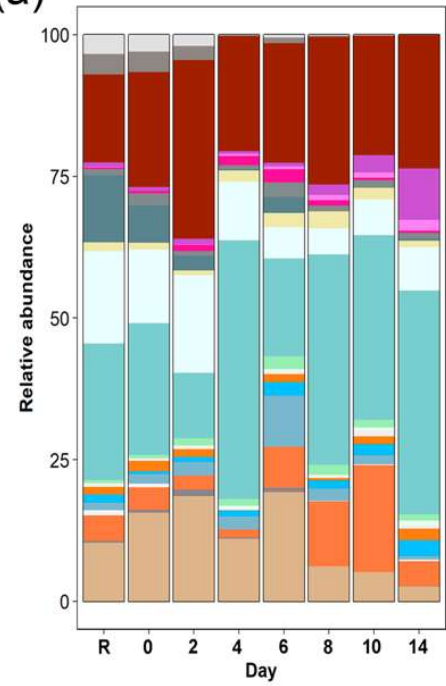

(b)

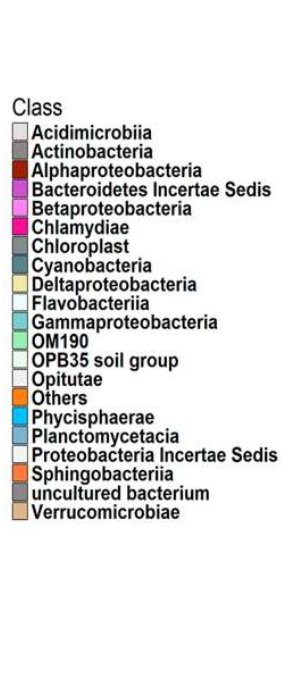

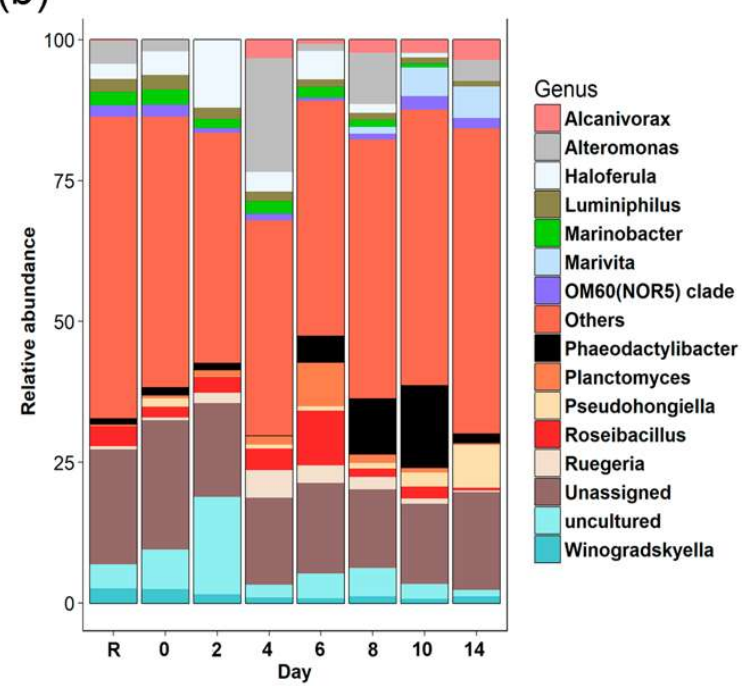

Figure 3. Relative abundances of the bacterioplankton community detected during the mesocosm experiment. (a) Classes (> 1\%). (b) Top twenty genera.

Table 3. PERVANOVA results. The table shows the variables significatively related to changes in the bacterial community structure.

\begin{tabular}{lcc}
\hline \multicolumn{1}{c}{ Variable } & $\mathbf{R}^{\mathbf{2}}$ & $\operatorname{Pr}(>\mathbf{F})$ \\
\hline Total Nitrogen & 0.22 & 0.030 \\
PAHs fraction & 0.25 & 0.048 \\
Naphthalene & 0.32 & 0.003 \\
1-metilnaphtalene & 0.025 & 0.041 \\
2-metilnaphtalene & 0.33 & 0.002 \\
Fluoranthene & 0.29 & 0.013 \\
Pyrene & 0.28 & 0.026 \\
Chrysene & 0.33 & 0.022 \\
Benzo(b)fluoranthene & 0.29 & 0.013 \\
Benzo(e)pyrene & 0.30 & 0.025 \\
Benzo(a)pyrene & 0.35 & 0.005 \\
Benzo(ghi)perylene & 0.30 & 0.020 \\
\hline
\end{tabular}

\subsection{Differential Abundance Analysis}

The differential ASVs belonging to Candidatus Thiobios, Candidatus Actinomarina, Acinetobacter, and Synechococcus were characteristic of days R and zero (Figure 4), while several unassigned ASVs were differentiated from initial time to day six. BLAST analyses from these unassigned ASVs, indicated that the sequences were related with the genera Lewinella (92.5\%), Prochlorococcus (96.37\%), Angustibacter (96.80\%), Ilumatobacter (97.2), and Candidatus Pelagibacter (96.78\%) (Table S1). Marinobacter was detected 
with differentiated abundances from the beginning of the experiment until day eight. From day eight until the end of the experiment, Marivita and Pseudohongiella were conspicuous (Figure 4).

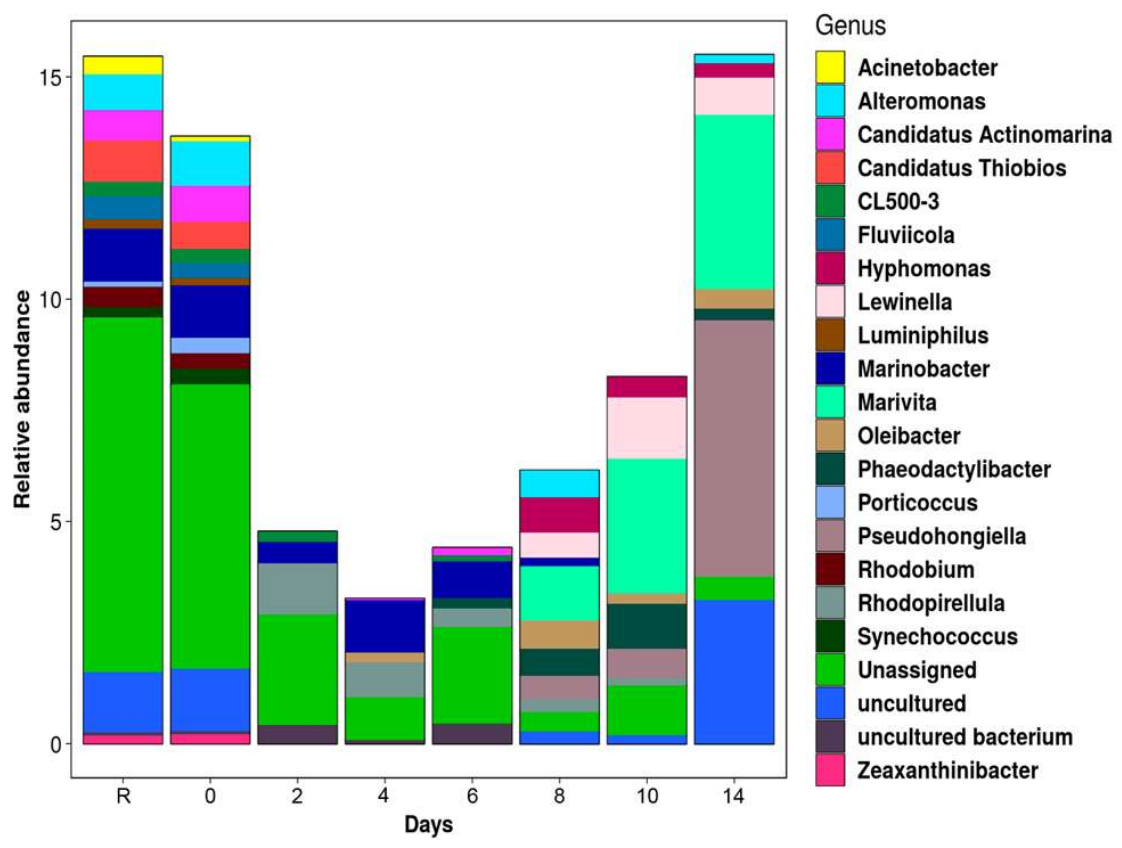

Figure 4. ASVs with differentiated relative abundances at genus level during the mesocosms experiment.

\section{Discussion}

The mesocosm design used for this research allowed to maintain similar environmental conditions to those previously reported for the superficial seawater from sGoM. The temperature, oxygen, salinity, and nutrient concentration measured during the mesocosm experiment were within the ranges previously reported for the water column of the Yucatan Peninsula [41,42]. The initial community composition of this study was comparable to the typical surface marine bacterioplankton, consisting of Alpha-proteobacteria, Gamma-proteobacteria, Flavobacteriia, and Cyanobacteria, as dominant members [43]. Thus, the results obtained from this study represent a proxy of the response of the native bacterioplankton community from sGoM to oil spills.

\subsection{Shifts in the Bacterioplankton Community after the Simulated Oil Spill}

In agreement with previous studies significant changes in the bacterial community were observed were observed after $48 \mathrm{~h}$ of exposition to crude oil [44-46]. During this time, considerable increases in the relative abundances of Alpha-proteobacteria and decreases in Cyanobacteria and Gamma-proteobacteria were observed (Figure 3b). These results differ from previous works in which increases in the relative abundances of Gamma-proteobacteria and Clostridia, have been observed during the initial period of expositions to contaminants in sites with low temperature $[47,48]$. We hypothesized that decreases in the relative abundances of Cyanobacteria could be related with the direct exposition to oil hydrocarbons, however the reduction in the amount of available light in the water column caused by the oil film on the surface, could be also associated with the affectation in the photosynthetic activity of Cyanobacteria.

Previous studies have reported a potential recovery of the bacterioplankton diversity in late periods of simulated hydrocarbon spills [49]. In concordance with this study, the diversity at the end of our experiment returned to similar values as those observed in the initial time. However, the bacterial composition was different from the initial community, which also in agreement with previous studies where it has been suggested that communities do not fully recover from the disturbance and move to an alternative stable state, where they can maintain their functional capacity $[7,50,51]$. 
In our study, some of the main changes in the bacterial composition after the simulated oil spill were related with decreases in the relative abundances of Candidatus Thiobio, Candidatus Actinomarina, Acinetobacter, and Synechococcus. Previous studies have reported to Synechococcus and Actinomarina as sensitive taxa for contaminated sites with heavy metals [52]. However, futures studies are needed in order to understand the oil effect over these genera.

Several works have demonstrated that changes in the bacterial community can be largely attributed to specific physicochemical parameters and hydrocarbons [53,54]. In this study, changes in the bacterioplankton structure were related to total nitrogen and the aromatic compounds concentrations, based on PERMANOVA analysis (Table 3). Accordingly, nitrogen had been related with the microbial growth and is commonly catalogued as limiting nutrient during crude oil degradation in natural environments [55]. Moreover, the persistence of aromatic hydrocarbons in the environment due to their low solubility have been well recognized to have influence on the bacterioplankton by previous studies [56-58].

\subsection{Hydrocarbonoclastic Bacterial Activity}

Previous mesocosm studies that have undertaken lower temperatures $\left(\leq 18{ }^{\circ} \mathrm{C}\right)$ have found that the main crude oil removal occurred from 15 to 20 days [21,59]. Unlikely, in this study the highest degradation activity was observed at day four, which highlight the importance of the seawater temperature for hydrocarbon degradation activity as previously was evidenced by Brackstad et al. [60].

During the period of highest crude oil degradation (day two to four), increases in the relative abundance of the Alteromonas, Haroferula, Rugeria, and Alcanivorax were distinctive (Figure 3b). These genera have been previously recognized to be involved in the degradation of aromatic and aliphatic hydrocarbons [61-68]. Therefore, we considered that these microorganisms have been related to the consumption of hydrocarbons in our experiment and may be explored for future bioremediation studies.

By the last stage of the experiment (days eight-14), increases in the relative abundances of Sphingobacteriia were observed (Figure 3a). Moreover, ASVs of Marivita and Oleibacter presented differential abundance in this period of the experiment (Figure 4). Previous studies have clearly showed that members of Sphingobacteriia can be n-alkane-degrading specialists [69]. Marivita belongs to the Roseobacter lineage (Alpha-proteobacteria) and has been reported to degrade aromatic and aliphatic compounds $[64,70,71]$. The genus Oleibacter has been reported with the capacity to degrade aliphatic hydrocarbons in tropical environments [72-74]. Based on the information presented above, we assume that Sphingobacteriia, Marivita, and Oleibacter had important participation related with the hydrocarbon degradation during the last days of our mesocosm system, however further research is required for a better understanding of its contribution in the microbial community.

\section{Conclusions}

The mesocosm experiment of this study evidenced a decrease in bacterioplankton diversity and changes in the community composition from sGoM after two days from the simulated oil spill. Increases in the relative abundances of Alpha-proteobacteria and decreases in Cyanobacteria and Gamma-proteobacteria were some of the main changes in the bacterial composition observed in this period of the experiment. According to the TPH concentration, counts of culturable hydrocarbonoclastic bacteria, and alkB gene copy number, the greatest hydrocarbon degradation activity performed by the bacterioplankton of sGoM occurred after four days from the disturbance. Alteromonas, Haloferula, Ruegiera, and Alcanivorax were found as the main groups putatively involved in the hydrocarbon degradation, based on increases in their relative abundances at this point of the experiment. Despite of the bacterial diversity being recovered at the end of the experiment (14 days), the community composition was different from the initial time. To our knowledge, this is the first mesocosm experiment to evaluate the effect of oil spills over the bacterioplankton community from sGoM. All the results 
presented here can be employed as a guideline for future studies aiming to evaluate bioremediation strategies for marine environments.

Supplementary Materials: The following are available online at http://www.mdpi.com/2076-2607/7/10/441/s1, Table S1. BLAST analysis of unassigned ASVs with differential abundances through the mesocosms experiment; Table S2: Concentrations of polycyclic aromatic hydrocarbons expressed in $\mu \mathrm{g} \cdot \mathrm{L}^{-1}$.

Author Contributions: Conceptualization, M.L.A.-M., J.Q.G.-M., D.P. and S.S.V.-A.; methodology, S.P., N.U.G.-C., M.M.U.-F. and J.H.-S.; software, D.C.-G.; validation, S.P. and J.Q.G.-M.; formal analysis, D.C.-G. and S.S.V.-A.; investigation, S.S.V.-A. and S.P.; resources, M.L.A.-M., D.P. and J.H.-S.; data curation, S.P., D.C.-G. and S.S.V.-A.; writing—original draft preparation, S.S.V.-A.; writing—review and editing, S.S.V.-A., M.M.U.-F., J.Q.G.-M., S.P., D.C.-G., N.U.G.-C., D.P., J.H.-S. and M.L.A.-M.; visualization, D.C.-G. and S.S.V.-A.; supervision, M.L.A.-M., J.Q.G.-M., D.P. and J.H.-S.; project administration, M.L.A.-M.; funding acquisition, M.L.A.-M., D.P. and J.H.-S.

Funding: This work was supported by 'Consejo Nacional de Ciencia y Tecnología' (CONACYT) [grants 15689-2014 and 251622-2015 to J.Q.G.M.] and by CONACYT-Mexican Ministry of Energy Hydrocarbon Trust [project 201441]. S.S.V.A received a CONACYT PhD fellowship 389671.

Acknowledgments: We would like to thank Rosa Cristina Canul Puc and Abril Gamboa Muñoz for technical support in the laboratory; Zita Arriaga Piñón and Roman Espinal for image edition. The quantification of hydrocarbon compounds was performed by Victor Ceja Moreno. The computational resources used for bioinformatics analyses were provided by Emanuel Hernández-Núñez. This is a contribution of the Gulf of Mexico Research Consortium (CIGoM).

Conflicts of Interest: The authors declare no conflict of interest.

\section{References}

1. Joye, S.B.; Bracco, A.; Özgökmen, T.M.; Chanton, J.P.; Grosell, M.; MacDonald, I.R.; Cordes, E.E.; Montoya, J.P.; Passow, U. The Gulf of Mexico Ecosystem, Six Years after the Macondo Oil Well Blowout. Deep Sea Res. Part II Top. Stud. Oceanogr. 2016, 129, 4-19. [CrossRef]

2. García-Cruz, N.U.; Aguirre-Macedo, M.L. Biodegradación de Petróleo Por Bacterias: Algunos Casos de Estudio En El Golfo de Mexico. In Golfo de México: Contaminación e Impacto Ambiental, Diagnóstico y Tendencias; Botello, A.V., Rendón von Osten, J., Benítez, J.A., Gold-Bouchot, G., Eds.; UAC, UNAM-ICMYL, CINVESTAV-Unidad Mérida: Mérida, Mexico, 2014; pp. 641-652.

3. Botello, A.V.; Soto, L.A.; Ponce-Vélez, G.; Susana Villanueva, F. Baseline for PAHs and Metals in NW Gulf of Mexico Related to the Deepwater Horizon Oil Spill. Estuar. Coast. Shelf Sci. 2015, 156, 124-133. [CrossRef]

4. Mapelli, F.; Scoma, A.; Michoud, G.; Aulenta, F.; Boon, N.; Borin, S.; Kalogerakis, N.; Daffonchio, D. Biotechnologies for Marine Oil Spill Cleanup: Indissoluble Ties with Microorganisms. Trends Biotechnol. 2017, 35, 860-870. [CrossRef] [PubMed]

5. Soto, L.A.; Botello, A.V.; Licea-Durán, S.; Lizárraga-Partida, M.L.; Yáñez-Arancibia, A. The Environmental Legacy of the Ixtoc-I Oil Spill in Campeche Sound, Southwestern Gulf of Mexico. Front. Mar. Sci. 2014, 1, 57. [CrossRef]

6. Lindh, M.V.; Pinhassi, J. Sensitivity of Bacterioplankton to Environmental Disturbance: A Review of Baltic Sea Field Studies and Experiments. Front. Mar. Sci. 2018, 5, 361. [CrossRef]

7. Shade, A.; Peter, H.; Allison, S.D.; Baho, D.L.; Berga, M.; Bürgmann, H.; Huber, D.H.; Langenheder, S.; Lennon, J.T.; Martiny, J.B.H.; et al. Fundamentals of Microbial Community Resistance and Resilience. Front. Microbiol. 2012, 3, 417. [CrossRef]

8. Hazen, T.C.; Dubinsky, E.A.; DeSantis, T.Z.; Andersen, G.L.; Piceno, Y.M.; Singh, N.; Jansson, J.K.; Probst, A.; Borglin, S.E.; Fortney, J.L.; et al. Deep-Sea Oil Plume Enriches Indigenous Oil-Degrading Bacteria. Science 2010, 330, 204-208. [CrossRef]

9. Kimes, N.E.; Callaghan, A.V.; Aktas, D.F.; Smith, W.L.; Sunner, J.; Golding, B.T.; Drozdowska, M.; Hazen, T.C.; Suflita, J.M.; Morris, P.J. Metagenomic Analysis and Metabolite Profiling of Deep-Sea Sediments from the Gulf of Mexico Following the Deepwater Horizon Oil Spill. Front. Microbiol. 2013, 4, 50. [CrossRef]

10. Kimes, N.E.; Callaghan, A.V.; Suflita, J.M.; Morris, P.J. Microbial Transformation of the Deepwater Horizon Oil Spill-Past, Present, and Future Perspectives. Front. Microbiol. 2014, 5, 603. [CrossRef]

11. King, G.M.; Kostka, J.E.; Hazen, T.C.; Sobecky, P.A. Microbial Responses to the Deepwater Horizon Oil Spill: From Coastal Wetlands to the Deep Sea. Ann. Rev. Mar. Sci. 2015, 7, 377-401. [CrossRef] 
12. Hazen, T.C. Lessons from the 2010 Deepwater Horizon Accident in the Gulf of Mexico. In Hydrocarbons, Oils and Lipids: Diversity, Origin, Chemistry and Fate; Wilkes, H., Ed.; Springer International Publishing: Cham, Switzerland, 2018; pp. 1-19. [CrossRef]

13. Marietou, A.; Chastain, R.; Beulig, F.; Scoma, A.; Hazen, T.C.; Bartlett, D.H. The Effect of Hydrostatic Pressure on Enrichments of Hydrocarbon Degrading Microbes from the Gulf of Mexico Following the Deepwater Horizon Oil Spill. Front. Microbiol. 2018, 9, 808. [CrossRef] [PubMed]

14. Kessler, J.D.; Valentine, D.L.; Redmond, M.C.; Du, M.; Chan, E.W.; Mendes, S.D.; Quiroz, E.W.; Villanueva, C.J.; Shusta, S.S.; Werra, L.M.; et al. A Persistent Oxygen Anomaly Reveals the Fate of Spilled Methane in the Deep Gulf of Mexico. Science 2011, 331, 312-315. [CrossRef] [PubMed]

15. Cappello, S.; Yakimov, M.M. Mesocosms for Oil Spill Simulation. In Handbook of Hydrocarbon and Lipid Microbiology; Timmis, K.N., Ed.; Springer: Berlin/Heidelberg, Germany, 2010; pp. 3513-3521. [CrossRef]

16. Wozniak, A.S.; Prem, P.M.; Obeid, W.; Waggoner, D.C.; Quigg, A.; Xu, C.; Santschi, P.H.; Schwehr, K.A.; Hatcher, P.G. Rapid Degradation of Oil in Mesocosm Simulations of Marine Oil Snow Events. Environ. Sci. Technol. 2019, 53, 3441-3450. [CrossRef] [PubMed]

17. Yamada, M.; Takada, H.; Toyoda, K.; Yoshida, A.; Shibata, A.; Nomura, H.; Wada, M.; Nishimura, M.; Okamoto, K.; Ohwada, K. Study on the Fate of Petroleum-Derived Polycyclic Aromatic Hydrocarbons (PAHs) and the Effect of Chemical Dispersant Using an Enclosed Ecosystem, Mesocosm. Mar. Pollut. Bull. 2003, 47, 105-113. [CrossRef]

18. Teira, E.; Lekunberri, I.; Gasol, J.M.; Nieto-Cid, M.; Álvarez-Salgado, X.A.; Figueiras, F.G. Dynamics of the Hydrocarbon-Degrading Cycloclasticus Bacteria during Mesocosm-Simulated Oil Spills. Environ. Microbiol. 2007, 9, 2551-2562. [CrossRef] [PubMed]

19. Cappello, S.; Denaro, R.; Genovese, M.; Giuliano, L.; Yakimov, M.M. Predominant Growth of Alcanivorax during Experiments on “Oil Spill Bioremediation” in Mesocosms. Microbiol. Res. 2007, 162, 185-190. [CrossRef] [PubMed]

20. Gertler, C.; Gerdts, G.; Timmis, K.N.; Golyshin, P.N. Microbial Consortia in Mesocosm Bioremediation Trial Using Oil Sorbents, Slow-Release Fertilizer and Bioaugmentation. FEMS Microbiol. Ecol. 2009, 69, 288-300. [CrossRef] [PubMed]

21. Hassanshahian, M.; Emtiazi, G.; Caruso, G.; Cappello, S. Bioremediation (Bioaugmentation/Biostimulation) Trials of Oil Polluted Seawater: A Mesocosm Simulation Study. Mar. Environ. Res. 2014, 95, 28-38. [CrossRef] [PubMed]

22. Doyle, S.M.; Whitaker, E.A.; De Pascuale, V.; Wade, T.L.; Knap, A.H.; Santschi, P.H.; Quigg, A.; Sylvan, J.B. Rapid Formation of Microbe-Oil Aggregates and Changes in Community Composition in Coastal Surface Water Following Exposure to Oil and the Dispersant Corexit. Front. Microbiol. 2018, 9, 689. [CrossRef]

23. García-Cruz, N.U.; Sánchez-Avila, J.I.; Valdés-Lozano, D.; Gold-Bouchot, G.; Aguirre-Macedo, L. Biodegradation of Hexadecane Using Sediments from Rivers and Lagoons of the Southern Gulf of Mexico. Mar. Pollut. Bull. 2018, 128, 202-207. [CrossRef]

24. Carrit, D.E.; Carpenter, J.H. Recommendation procedure for Winkler analyses of sea water for dissolved oxygen. J. Mar. Res. 1966, 24, 313-318.

25. Bryan, J.R.; Riley, J.P.; Williams, P.J. A Winkler Procedure for Making Precise Measurements Studies. J. Exp. Mar. Biol. Ecol. 1976, 21, 191-197. [CrossRef]

26. Williams, P.J.l.B.; Jenkinson, N.W. A Transportable Microprocessor-controlled Precise Winkler Titration Suitable for Field Station and Shipboard Use. Limnol. Oceanogr. 1982, 27, 576-584. [CrossRef]

27. Strickland, J.D.H.; Parsons, T.R. A Practical Hand Book of Seawater Analysis, 2nd ed.; Fisheries Research Board of Canada Bulletin: Ottawa, ON, Canada, 1972; pp. 157-310.

28. Lizárraga-Partida, M.L.; Izquierdo-Vicuña, F.B.; Wong-Chang, I. Marine Bacteria on the Campeche Bank Oil Field. Mar. Pollut. Bull. 1991, 22, 401-405. [CrossRef]

29. Uribe-Flores, M.M.; Cerqueda-García, D.; Hernández-Nuñez, E.; Cadena, S.; García-Cruz, N.U.; Trejo-Hernández, M.R.; Aguirre-Macedo, M.L.; García-Maldonado, J.Q. Bacterial Succession and Co-Occurrence Patterns of an Enriched Marine Microbial Community during Light Crude Oil Degradation in a Batch Reactor. J. Appl. Microbiol. 2019, 127, 495-507. [CrossRef] [PubMed]

30. Klindworth, A.; Pruesse, E.; Schweer, T.; Peplies, J.; Quast, C.; Horn, M.; Glöckner, F.O. Evaluation of General 16S Ribosomal RNA Gene PCR Primers for Classical and Next-Generation Sequencing-Based Diversity Studies. Nucleic Acids Res. 2013, 41, e1. [CrossRef] [PubMed] 
31. Caporaso, J.G.; Kuczynski, J.; Stombaugh, J.; Bittinger, K.; Bushman, F.D.; Costello, E.K.; Fierer, N.; Gonzalez-Peña, A.; Goodrich, J.K.; Gordon, J.I.; et al. QIIME Allows Analysis of High-Throughput Community Sequencing Data. Nat. Methods 2010, 7, 335-336. [CrossRef]

32. Callahan, B.J.; McMurdie, P.J.; Rosen, M.J.; Han, A.W.; Johnson, A.J.A.; Holmes, S.P. DADA2: High-Resolution Sample Inference from Illumina Amplicon Data. Nat. Methods 2016, 13, 581-583. [CrossRef]

33. Callahan, B.J.; McMurdie, P.J.; Holmes, S.P. Exact Sequence Variants Should Replace Operational Taxonomic Units in Marker-Gene Data Analysis. ISME J. 2017, 11, 2639-2643. [CrossRef]

34. Rognes, T.; Flouri, T.; Nichols, B.; Quince, C.; Mahé, F. VSEARCH: A Versatile Open Source Tool for Metagenomics. PeerJ 2016, 4, e2584. [CrossRef]

35. Price, M.N.; Dehal, P.S.; Arkin, A.P. FastTree 2-Approximately Maximum-Likelihood Trees for Large Alignments. PLoS ONE 2010, 5, e9490. [CrossRef] [PubMed]

36. McMurdie, P.J.; Holmes, S. Phyloseq: An R Package for Reproducible Interactive Analysis and Graphics of Microbiome Census Data. PLoS ONE 2013, 8, e61217. [CrossRef] [PubMed]

37. Oksanen, J.; Blanchet, F.G.; Kindt, R.; Legendre, P.; Minchin, P.R.; O’Hara, R.B.; Simpson, G.L.; Solymos, P.; Stevens, M.H.H.; Wagner, H. Vegan: Community Ecology Package. R Package Version 2.0-10. 2013. Available online: http://CRAN.R-project.org/package=vegan (accessed on 1 July 2019).

38. Wickham, H. Ggplot2: Elegant Graphics for Data Analysis; Springer: New York, NY, USA, 2009; p. 213.

39. Lozupone, C.; Knight, R. UniFrac: A New Phylogenetic Method for Comparing Microbial Communities. Appl. Environ. Microbiol. 2005, 71, 8228-8235. [CrossRef] [PubMed]

40. Lozupone, C.A.; Knight, R. Global Patterns in Bacterial Diversity. Proc. Natl. Acad. Sci. USA 2007, 104, 11436-11440. [CrossRef] [PubMed]

41. Herrera-Silveira, J.A.; Medina-Gomez, I.; Colli, R. Trophic Status Based on Nutrient Concentration Scales and Primary Producers Community of Tropical Coastal Lagoons Influenced by Groundwater Discharges. Hydrobiologia 2002, 475, 91-98. [CrossRef]

42. Herrera-Silveira, J.A.; Comin, F.A.; Aranda-Cirerol, N.; Troccoli, L.; Capurro, L. Coastal Water Quality Assessment in the Yucatan Peninsula: Management Implications. Ocean Coast. Manag. 2004, 47, 625-639. [CrossRef]

43. Overmann, J.; Lepleux, C. Marine Bacteria and Archaea: Diversity, Adaptations, and Culturability. In the Marine Microbiome; Stal, L.J., Cretoiu, M.S., Eds.; Springer: Cham, Switzerland, 2016; pp. 21-55.

44. Lanfranconi, M.P.; Bosch, R.; Nogales, B. Short-Term Changes in the Composition of Active Marine Bacterial Assemblages in Response to Diesel Oil Pollution. Microb. Biotechnol. 2010, 3, 607-621. [CrossRef] [PubMed]

45. Vila, J.; Nieto, J.M.; Mertens, J.; Springael, D.; Grifoll, M. Microbial Community Structure of a Heavy Fuel Oil-Degrading Marine Consortium: Linking Microbial Dynamics with Polycyclic Aromatic Hydrocarbon Utilization. FEMS Microbiol. Ecol. 2010, 73, 349-362. [CrossRef]

46. Morris, L.; O’Brien, A.; Natera, S.H.A.; Lutz, A.; Roessner, U.; Long, S.M. Structural and Functional Measures of Marine Microbial Communities: An Experiment to Assess Implications for Oil Spill Management. Mar. Pollut. Bull. 2018, 131, 525-529. [CrossRef]

47. Gertler, C.; Näther, D.J.; Cappello, S.; Gerdts, G.; Quilliam, R.S.; Yakimov, M.M.; Golyshin, P.N. Composition and Dynamics of Biostimulated Indigenous Oil-Degrading Microbial Consortia from the Irish, North and Mediterranean Seas: A Mesocosm Study. FEMS Microbiol. Ecol. 2012, 81, 520-536. [CrossRef]

48. Dellagnezze, B.M.; Vasconcellos, S.P.; Angelim, A.L.; Melo, V.M.M.; Santisi, S.; Cappello, S.; Oliveira, V.M. Bioaugmentation Strategy Employing a Microbial Consortium Immobilized in Chitosan Beads for Oil Degradation in Mesocosm Scale. Mar. Pollut. Bull. 2016, 107, 107-117. [CrossRef] [PubMed]

49. Rodriguez-R, L.M.; Overholt, W.A.; Hagan, C.; Huettel, M.; Kostka, J.E.; Konstantinidis, K.T. Microbial Community Successional Patterns in Beach Sands Impacted by the Deepwater Horizon Oil Spill. ISME J. 2015, 9, 1928-1940. [CrossRef] [PubMed]

50. Röling, W.F.M.; Milner, M.G.; Jones, D.M.; Lee, K.; Daniel, F.; Swannell, R.J.P.; Head, I.M. Robust Hydrocarbon Degradation and Dynamics of Bacterial Communities during Nutrient-Enhanced Oil Spill Bioremediation. Appl. Environ. Microbiol. 2002, 68, 5537-5548. [CrossRef] [PubMed]

51. Herzyk, A.; Fillinger, L.; Larentis, M.; Qiu, S.; Maloszewski, P.; Hünniger, M.; Schmidt, S.I.; Stumpp, C.; Marozava, S.; Knappett, P.S.K.; et al. Response and Recovery of a Pristine Groundwater Ecosystem Impacted by Toluene Contamination-A Meso-Scale Indoor Aquifer Experiment. J. Contam. Hydrol. 2017, 207, 17-30. [CrossRef] 
52. Coclet, C.; Garnier, C.; Durrieu, G.; Omanović, D.; D'Onofrio, S.; Le Poupon, C.; Mullot, J.U.; Briand, J.F.; Misson, B. Changes in Bacterioplankton Communities Resulting from Direct and Indirect Interactions with Trace Metal Gradients in an Urbanized Marine Coastal Area. Front. Microbiol. 2019, 10, 257. [CrossRef]

53. Paissé, S.; Coulon, F.; Goñi-Urriza, M.; Peperzak, L.; McGenity, T.J.; Duran, R. Structure of Bacterial Communities along a Hydrocarbon Contamination Gradient in a Coastal Sediment. FEMS Microbiol. Ecol. 2008, 66, 295-305. [CrossRef]

54. Torstensson, A.; Dinasquet, J.; Chierici, M.; Fransson, A.; Riemann, L.; Wulff, A. Physicochemical Control of Bacterial and Protist Community Composition and Diversity in Antarctic Sea Ice. Environ. Microbiol. 2015, 17, 3869-3881. [CrossRef]

55. Hazen, T.C.; Prince, R.C.; Mahmoudi, N. Marine Oil Biodegradation. Environ. Sci. Technol. 2016, 50, 2121-2129. [CrossRef]

56. Wammer, K.H.; Peters, C.A. Polycyclic Aromatic Hydrocarbon Biodegradation Rates: A Structure-Based Study. Environ. Sci. Technol. 2005, 39, 2571-2578. [CrossRef]

57. Wang, B.; Lai, Q.; Cui, Z.; Tan, T.; Shao, Z. A Pyrene-Degrading Consortium from Deep-Sea Sediment of the West Pacific and Its Key Member Cycloclasticus Sp. P1. Environ. Microbiol. 2008, 10, 1948-1963. [CrossRef]

58. Sun, L.; Chiu, M.H.; Xu, C.; Lin, P.; Schwehr, K.A.; Bacosa, H.; Kamalanathan, M.; Quigg, A.; Chin, W.C.; Santschi, P.H. The Effects of Sunlight on the Composition of Exopolymeric Substances and Subsequent Aggregate Formation During Oil Spills. Mar. Chem. 2018, 203, 49-54. [CrossRef]

59. Cappello, S.; Caruso, G.; Zampino, D.; Monticelli, L.S.; Maimone, G.; Denaro, R.; Tripodo, B.; Troussellier, M.; Yakimov, M.; Giuliano, L. Microbial Community Dynamics during Assays of Harbour Oil Spill Bioremediation: A Microscale Simulation Study. J. Appl. Microbiol. 2007, 102, 184-194. [CrossRef] [PubMed]

60. Brakstad, O.G.; Daling, P.S.; Faksness, L.G.; Almås, I.K.; Vang, S.H.; Syslak, L.; Leirvik, F. Depletion and Biodegradation of Hydrocarbons in Dispersions and Emulsions of the Macondo 252 Oil Generated in an Oil-on-Seawater Mesocosm Flume Basin. Mar. Pollut. Bull. 2014, 84, 125-134. [CrossRef] [PubMed]

61. Gutierrez, T. Marine, Aerobic Hydrocarbon-Degrading Gammaproteobacteria: Overview. In Taxonomy, Genomics and Ecophysiology of Hydrocarbon-Degrading Microbes. Handbook of Hydrocarbon and Lipid Microbiology; Mcgenity, T.J., Ed.; Springer: Cham, Switzerland, 2017; pp. 1-10.

62. Yakimov, M.M.; Timmis, K.N.; Golyshin, P.N. Obligate Oil-Degrading Marine Bacteria. Curr. Opin. Biotechnol. 2007, 18, 257-266. [CrossRef] [PubMed]

63. Dombrowski, N.; Donaho, J.A.; Gutierrez, T.; Seitz, K.W.; Teske, A.P.; Baker, B.J. Reconstructing Metabolic Pathways of Hydrocarbon-Degrading Bacteria from the Deepwater Horizon Oil Spill. Nat. Microbiol. 2016, 1, 16057. [CrossRef] [PubMed]

64. Buchan, A.; González, J.M.; Chua, M.J. Aerobic Hydrocarbon-Degrading Alphaproteobacteria: Rhodobacteraceae (Roseobacter). In Taxonomy, Genomics and Ecophysiology of Hydrocarbon-Degrading Microbes; Mcgenity, T.J., Ed.; Springer: Cham, Switzerland, 2019; pp. 1-13. [CrossRef]

65. Guibert, L.M.; Loviso, C.L.; Borglin, S.; Jansson, J.K.; Dionisi, H.M.; Lozada, M. Diverse Bacterial Groups Contribute to the Alkane Degradation Potential of Chronically Polluted Subantarctic Coastal Sediments. Microb. Ecol. 2016, 71, 100-112. [CrossRef] [PubMed]

66. Varjani, S.J. Microbial Degradation of Petroleum Hydrocarbons. Bioresour. Technol. 2017, 223, $277-286$. [CrossRef]

67. Rochman, F.F. Aerobic Hydrocarbon-Degrading Microbial Communities in Oilsands Tailings Ponds. Ph.D. Thesis, University of Calgary, Calgary, AB, Canada, 2016.

68. Chikere, C.B.; Mordi, I.J.; Chikere, B.O.; Selvarajan, R.; Ashafa, T.O.; Obieze, C.C. Comparative Metagenomics and Functional Profiling of Crude Oil-Polluted Soils in Bodo West Community, Ogoni, with Other Sites of Varying Pollution History. Ann. Microbiol. 2019, 69, 495-513. [CrossRef]

69. Woźniak-Karczewska, M.; Lisiecki, P.; Białas, W.; Owsianiak, M.; Piotrowska-Cyplik, A.; Wolko, Ł.; Ławniczak, Ł.; Heipieper, H.J.; Gutierrez, T.; Chrzanowski, Ł. Effect of Bioaugmentation on Long-Term Biodegradation of Diesel/Biodiesel Blends in Soil Microcosms. Sci. Total Environ. 2019, 671, 948-958. [CrossRef]

70. Hwang, C.Y.; Bae, G.D.; Yih, W.; Cho, B.C. Marivita Cryptomonadis Gen. Nov., Sp. Nov. and Marivita Litorea Sp. Nov., of the Family Rhodobacteraceae, Isolated from Marine Habitats. Int. J. Syst. Evolut. Microbiol. 2009, 59, 1568-1575. [CrossRef] 
71. Daniel, R.; Simon, M.; Wemheuer, B. Editorial: Molecular Ecology and Genetic Diversity of the Roseobacter Clade. Front. Microbiol. 2018, 9, 1185. [CrossRef] [PubMed]

72. Lofthus, S.; Netzer, R.; Lewin, A.S.; Heggeset, T.M.B.; Haugen, T.; Brakstad, O.G. Biodegradation of N-Alkanes on Oil-Seawater Interfaces at Different Temperatures and Microbial Communities Associated with the Degradation. Biodegradation 2018, 29, 141-157. [CrossRef] [PubMed]

73. Teramoto, M.; Queck, S.Y.; Ohnishi, K. Specialized Hydrocarbonoclastic Bacteria Prevailing in Seawater around a Port in the Strait of Malacca. PLoS ONE 2013, 8, e66594. [CrossRef]

74. Teramoto, M.; Suzuki, M.; Okazaki, F.; Hatmanti, A.; Harayama, S. Oceanobacter-Related Bacteria Are Important for the Degradation of Petroleum Aliphatic Hydrocarbons in the Tropical Marine Environment. Microbiology 2009, 155, 3362-3370. [CrossRef] [PubMed]

(C) 2019 by the authors. Licensee MDPI, Basel, Switzerland. This article is an open access article distributed under the terms and conditions of the Creative Commons Attribution (CC BY) license (http://creativecommons.org/licenses/by/4.0/). 